\title{
Editorial 2015/X/2
}

\section{Jana Dlouhá}

Envigogika 10 (2) - Editorial

Publikováno/Published 2. 10. 2015

DOI: $\underline{10.14712 / 18023061.497}$

Vážení čtenáři Envigogiky,

začněme tentokrát pozitivně - minulý týden proběhl celosvětový summit v New Yorku, který schválil dohromady 17 cílů udržitelného rozvoje, což má být společná agenda světa do roku 2030. Jsou zde shrnuty základní předpoklady důstojného života, které ovšem nejsou samozřejmě dostupné pro každého člověka naší planety; představitelé 160 států včetně ČR (reprezentoval ji vicepremiér Bělobrádek) se ted' zavázali, že tuto situaci zlepší. Jak ukazuje Glopolis, z celkového množství 169 schválených podcílü je většina relevantních též pro Českou republiku (163); nejvíc "domácích úkolư" má rezort MŽP (34), a školství zajištúuje $10 \mathrm{z}$ nich (další je ovšem potřeba řešit v meziresortní spolupráci). Celosvětově je analyzována startovní pozice jednotlivých zemí v tomto procesu: můžeme tak srovnávat, jak si v různých oblastech stojí ČR. Ukazuje se, že jsme premianty v oblasti vzdělávání, protože $92,8 \%$ z nás ukončilo alespoň střední školu. Podle statistických zdrojů (Global Education Digest, 2011, str. 144) se ovšem tento ukazatel (dosažené "nižší středoškolské vzdělání", ISCED 2) vztahuje na děti od 11 do 15 let - v našem systému tak jde o základní školu a naší zásluhou tedy je, že ji dokončilo (po Japonsku) nejvíc dětí. Takže můžeme jen doufat, že si Česká republika nevezme toto (téměř) prvenství za vzor pro práci v dalších oblastech, a že směrem k roku 2030 se budeme posouvat $v$ souladu s našimi mezinárodními závazky ke skutečné kvalitě a (nebojme se to říci) pokroku.

Současné debaty o "transformaci vzdělávacího systému směrem k udržitelnosti", jak se celému procesu $v$ naší oblasti poměrně šroubovaně říká, jsou pro nás př́ležitosti $k$ novému zamyšlení nad smyslem a cíli vzdělávaní v dnešní "výkonnostně orientované" době. Toto číslo Envigogiky sleduje, jaké možnosti se $v$ tomto prostoru na různých úrovních otevírají, a jak je Ize uchopit $v$ samotné praxi. Přinášíme vám tak např́klad zprávu o současném stavu „ozelenění" vysokých škol v Srbsku (autoři Vesna Nikolić, Jelena Ranitović a Slobodan Milutinović ukazuji hlavně, jak je termín „udržitelný rozvoj" různým způsobem (ne)pochopen $v$ tamní VŠ politice a praxi). Podobné téma metodicky zpracovávají autorky Jana Ružičková, Marta Nevřelová a Blanka Lehotská pro slovenské prostředí - analyzují programy Př́rodovědecké fakulty UK v Bratislavě (dospívají k závěru, že přes všechny chvályhodné snahy a posuny zde chybí některá důležitá témata). Nakonec též vidíme, jak se vysokoškolské vzdělání v Arménii $v$ současném období všeobecných proměn zaměřuje na kompetence $v$ ochraně prírody a podporuje další schopnosti související $s$ účastí při rozhodování - o tom píše autorka Gayane Poghosyan se svými kolegy. Všechny tyto zprávy o 
(často ojedinělých) snahách změnit logiku a fungování celého systému vzdělávání mají jedno společné: porozumění hlavnímu argumentu pro tuto změnu - pojmu „udržitelný rozvoj" - se liší v různých kulturách a též podle dějinných souvislostí, což má pak v praxi mnoho různorodých projevů či dopadů.

A už se ve svých úvahách přesunujeme na úroveň základních škol, pro které Jan Bartoš a Tomáš Matějček popisují výzkum zaměřený na problematiku environmentálních postojů mj. sledují, jak o nich učitelé přemýšlí a pracuji s nimi ve výuce, anebo zda dochází k přenosu postojů mezi žáky a jejich rodiči. $Z$ hodnocení (na druhé straně) mimoškolní výchovy v dlouhodobém programu "Dva jsou víc než jeden" se ukazuje, které metody přispívají

k inkluzi ve vzdělávání, a to z hlediska osobnostně sociální výchovy, environmentální výchovy a řemesIných činností (autoři Lenka Broukalová, Václav Broukal, Jan Činčera a Zdeňka Sopůšková dokládají, že jednoznačně nejvhodnější jsou právě řemeslné aktivity). Na závěr tohoto (neúplného) obrázku o probíhajících posunech v pedagogických přístupech a praxi se dotkneme i škol mateřských - autorky Viera Novanska, Jana Škvarková a Bohumila Barková zde nabízejí soubor indikátorů udržitelného rozvoje, který Ize použít při interních auditech a tedy pro účely vnitřní proměny mateřských škol. Předškolnímu vzdělávání se věnují také dva informační texty popisující výsledky jedné cesty do Berlína za tamními (pěti) lesními mateřskými školami a (jedním) centrem výzkumu pro děti (Tereza Valkounová), i ještě daleko napínavější príiběh o tom, jak byla lesní alternativa předškolního vzdělávání v České republice nakonec (po dlouhém snažení několika dobrých duchů) zachráněna - jak píše Vendula Soběslavská.

Věnujte prosím pozornost též textu povahy inspirační, který jsme pro vás přeložili z časopisu Science. Zabývá se propojením přírodovědného a environmentálního vzdělávání - autoři (Arjen Wals a jeho kolegové) prosazují širokou spolupráci mezi vědci, učiteli a veřejností, založenou například na soustavném rozšiřování oborového pohledu o mezioborové souvislosti, nebo vytváření vztahů mezi vědeckými informacemi a tradičními znalostmi (domorodými zkušenostmi a místně zakotvenými poznatky). Znamená to, že ačkoliv se přírodovědné vzdělávání vyvíjelo dlouhou dobu odděleně od environmentálního, současný výzkum a vývoj v obou oblastech ukazuje na nutnost posilování vazeb mezi nimi, přičemž lze zapojit též laickou veřejnost. $K$ tomu směřuje tzv. občanská věda - označení pro postup, kdy místní občané mohou sami monitorovat změny životního prostředí s využitím rozmanitých technologií a data předávat vědcům ke zpracování.

To je $v$ tomto čisle vše, číst si ale můžete i v textech, které průběžně přibývají v dalších připravovaných číslech Envigogiky, z nichž jedno vyjde do konce tohoto roku.

Krásné podzimní dny u zajímavého čtení přeje

Redakce Envigogiky 